\title{
The Developing Model of Aviation Economy to Support the Destination as a Hub City
}

\author{
AmyMya Menghua LIU, Shun $\mathrm{YI}^{*}$ and Shan-shan YUAN \\ ${ }^{1}$ South China Business College, Guangdong University of Foreign Studies, Guangzhou, P.R.C \\ 2Zhao Qing University, Zhaoqing, P.R.C \\ ${ }^{3}$ Nanchang University, Guangzhou, P.R.C \\ ${ }^{*}$ Corresponding author
}

\begin{abstract}
Keywords: Airport economic zone, Passenger hub city, Guangdong-Hong Kong-Macau great bay area, Airport City, Destination Management.
\end{abstract}

\begin{abstract}
With the deepening development of National Airport Economic Zone in Beijing, Shanghai, Zhengzhou and other cities during China's '13 Fifth-Year Plan' period, the impact of the aviation economy on cities has become increasingly important. The aviation economy has a rapid growth in the regional economy, triggering a dispute between the construction of 'Aviation hub Cities' and concept of 'Smart Cities'. Through the field survey, it has been found that it is a long way to go to drive 'Smart City' by aviation. There are five typical models in 'stably growing aviation economy support hub cities' in the world: Anglo-American 'Airport Cities Cluster', European 'Integrated Small and Medium Business Airports', Shanghai 'One City and Two Regional Airports Transport', Zhengzhou 'Aviation Free Trade Zone' and Hong Kong Airport 'Integrated Passenger Transport'. This article takes the airline passenger hub city as the entry point, and proposes that the National Airport Economy Zone, such as Guangzhou, should pay attention to the development of passenger transport, convert passengers into tourists, and learn from the experience of domestic and foreign aviation cities through the development of tourism economy, from the inspiration of planning transformation, business philosophy, institutional innovation and publicity and promotion. It is also believed that hub cities such as Zhuhai and Shenzhen should develop aviation flow economy first and then reach the goal of aviation economic development supporting passenger hub city's development. That is why they can also complete the task of developing the airport economic zone, and eventually develop into an aviation city.
\end{abstract}

\section{Introduction}

The construction of hub city has played an increasingly important role in the implementation of the 'One Belt One Road' initiative. Functions of shipping hubs such as Guangzhou, Changsha and Qingdao will meet new opportunities and challenges for aviation services due to the development of the China National Airport Economic Zone. The necessity of actively strengthening the aviation economy to support the passenger hub cities is further highlighted. First, the rapid development of the aviation economy model at large airports and airport development zones has also strengthened the core competitiveness of urban destinations at home and abroad. It has been described as a cure for the scarcity of urban land and a shrinking property of financial market ${ }^{[1,2,3,4]}$. Domestically, seven major state-level airport economic zones such as Zhengzhou have achieved great economic effects. Zhengzhou International Airport was opened in 1997. Intercity light rail links with surrounding cities such as Zhengzhou and Kaifeng. The subway shortens the distance between the airport and the city into 30 minutes. In 2014, with the success of the aviation economic test zone, Zhengzhou became one of the 15 busiest airports in China, with nearly 20 million passenger throughputs per year. The economic benefits have exceeded some national economic development zones. By January 2016, the airport's GDP reached 52 billion yuan (a growth rate of 22.5\%), the industrial added value above designated size was 42.9 billion (a growth of 25.9\%), and the foreign trade import and export volume was 48.3 billion (a growth rate of $27.5 \%$ ). Although there is a 
decrease in import and export growth rate, it is better than that of Zhengzhou and Henan,that is the best city of this area. In the process of the China's hub cities construction, such as Zhengzhou, Greenland Group highly praised the 'transition of the airport industry to high-end and modern service' and took 'industries such as high-end manufacturing, high-tech industries and service industries as the main industries'. This transitional mode has also entered urban expansion horizon. Recent years, the Airports Economic Development Zone has sprung up like Hangzhou, Qingdao, Chongqing, Guizhou, Changsha and Wuhan.

Table 1. Development profile of China's major national airport economy zone

\begin{tabular}{|c|c|c|c|c|c|c|c|}
\hline Name & $\begin{array}{l}\text { Locatio } \\
\mathbf{n}\end{array}$ & $\begin{array}{l}\text { Startu } \\
\text { p } \\
\text { Period }\end{array}$ & $\begin{array}{l}\text { Turning } \\
\text { Period }\end{array}$ & Area & Scale & $\begin{array}{l}\text { Supporting } \\
\text { Industrial }\end{array}$ & 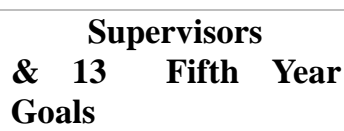 \\
\hline $\begin{array}{l}\text { Beijing } \\
\text { Airport } \\
\text { Econom } \\
\text { ic Core } \\
\text { Area }\end{array}$ & Beijing & 2006 & $\begin{array}{l}2012 \\
2014\end{array}$ & $\begin{array}{l}\text { Shunyi } \\
\text { District }\end{array}$ & $\begin{array}{l}170 \\
\mathrm{~km}^{2}\end{array}$ & $\begin{array}{l}\text { Beijing-Tianjin- } \\
\text { Hebei integrated } \\
\text { industry }\end{array}$ & $\begin{array}{l}\text { Aviation science and } \\
\text { technology,e-commerc } \\
\text { e at the provincial level } \\
\text { (actively coordinating } \\
\text { Beijing-Tianjin-Hebei } \\
\text { Airport, building a } 270 \\
\text { billion industry) }\end{array}$ \\
\hline $\begin{array}{l}\text { Hongqia } \\
\text { o } \\
\text { Airport } \\
\text { Econom } \\
\text { ic Zone }\end{array}$ & $\begin{array}{l}\text { Shangha } \\
\text { i }\end{array}$ & 2006 & 2009 & $\begin{array}{l}\text { Chang- } \\
\text { ning } \\
\text { District }\end{array}$ & $\begin{array}{c}13.89 \\
\mathrm{~km}^{2}\end{array}$ & $\begin{array}{l}\text { Aviation and } \\
\text { Business }\end{array}$ & $\begin{array}{l}\text { Provincial (provincial } \\
\text { economic development } \\
\text { zone with national } \\
\text { honor and commercial } \\
\text { function) }\end{array}$ \\
\hline $\begin{array}{l}\text { Guangz } \\
\text { hou } \\
\text { Airport } \\
\text { Econom } \\
\text { ic Zone }\end{array}$ & $\begin{array}{l}\text { Guangzh } \\
\text { ou }\end{array}$ & 2010 & $\begin{array}{l}2013 \\
2015\end{array}$ & $\begin{array}{l}\text { Huadu } \\
\text { Distric; } \\
\text { Baiyun } \\
\text { Distric }\end{array}$ & $\begin{array}{l}135 \\
\mathrm{~km}^{2}\end{array}$ & $\begin{array}{c}\text { Aviation; } \\
\text { Logistics; } \\
\text { Leasing finance. }\end{array}$ & $\begin{array}{l}\text { City level (one of the } \\
\text { global integrated } \\
\text { aviation hubs, Asian } \\
\text { logistics hubs, and } \\
\text { China's important } \\
\text { airport economy) }\end{array}$ \\
\hline $\begin{array}{l}\text { Jiaodon } \\
\text { g } \\
\text { Airport } \\
\text { Econom } \\
\text { ic } \\
\text { Demons } \\
\text { tration } \\
\text { Zone }\end{array}$ & Qingdao & 2005 & 2016 & $\begin{array}{l}\text { Jiaozho } \\
\text { u City; } \\
\text { Pingdu } \\
\text { City }\end{array}$ & $\begin{array}{l}149 \\
\mathrm{~km}^{2}\end{array}$ & $\begin{array}{l}\text { Fisheries and } \\
\text { Modern service }\end{array}$ & $\begin{array}{l}\text { City level (Maritime } \\
\text { Silk Road Core Area, } \\
\text { Northeast Asian } \\
\text { International Hub) }\end{array}$ \\
\hline $\begin{array}{l}\text { Chongqi } \\
\text { ng } \\
\text { Airport } \\
\text { City }\end{array}$ & $\begin{array}{l}\text { Chongqi } \\
\text { ng }\end{array}$ & 2010 & $\begin{array}{l}2010 \\
2015\end{array}$ & $\begin{array}{c}\text { Yubei } \\
\text { District }\end{array}$ & $\begin{array}{l}16.59 \\
\mathrm{~km}^{2}\end{array}$ & $\begin{array}{l}\text { Modern } \\
\text { Logistics, } \\
\text { Airport } \\
\text { intelligence } \\
\text { etc }\end{array}$ & $\begin{array}{l}\text { Provincial Level (Air } \\
\text { Intelligent } \\
\text { Manufacturing Base, } \\
\text { Aviation Smart Town) }\end{array}$ \\
\hline $\begin{array}{l}\text { Xinzhen } \\
\text { g } \\
\text { Compre } \\
\text { hensive } \\
\text { Free } \\
\text { Trade } \\
\text { Zone }\end{array}$ & $\begin{array}{l}\text { Zhengzh } \\
\text { ou }\end{array}$ & 2010 & 2015 & $\begin{array}{l}\text { Airport } \\
\text { Area }\end{array}$ & $\begin{array}{l}415 \\
\mathrm{~km}^{2}\end{array}$ & $\begin{array}{c}\text { International } \\
\text { Logistics, } \\
\text { Aviation , Smart } \\
\text { Terminal } \\
\text { (Mobile) }\end{array}$ & $\begin{array}{c}\text { Provincial level } \\
\text { (Central Plains } \\
\text { Economic Growth, } \\
\text { Modern Aviation City) }\end{array}$ \\
\hline $\begin{array}{l}\text { Changsh } \\
\text { a } \\
\text { Airport } \\
\text { Econom } \\
\text { ic Zone }\end{array}$ & $\begin{array}{c}\text { Changsh } \\
\text { a }\end{array}$ & 2008 & 2017 & $\begin{array}{l}\text { Yihua } \\
\text { District; } \\
\text { Furong } \\
\text { District }\end{array}$ & $\begin{array}{l}261 \\
\mathrm{~km}^{2}\end{array}$ & $\begin{array}{l}\text { Cross-border } \\
\text { e-commerce; } \\
\text { Airports } \\
\text { manufacturing; } \\
\text { Top-grade } \\
\text { ecological hotel }\end{array}$ & $\begin{array}{l}\text { City level (one hundred } \\
\text { billion industry, } 33 \\
\text { million passengers, } \\
400,000 \text { tons freight) }\end{array}$ \\
\hline
\end{tabular}

Source rom the official website of economic zone, referring to the academic research results of Professor Cao Yunchun (2011).

Second, the fast and comprehensive transportation system is the foundation for supporting airport as a gateway to city ${ }^{1}$. On the one hand, the key to build an aviation hub city is the ability of network 
transportation. By the end of 2017, China also announced the 13th five-year international hub aviation cities, including Harbin, Shenzhen, Chengdu, Kunming, Chongqing, Xi'an, and Urumqi. Most of these cities are in the important transport nodes along the Belt and Road. Chengdu and Guangzhou have directly formed a catch-up trend for passenger transport. At present, Guangdong-Hong Kong-Macao Area are actively planning international aviation hub cities. Compared with the international aviation city cluster, Guangdong-Hong Kong-Macau have the largest volume of passengers and cargo in the Dawan Area. However, the average number of airline trips per person in Guangdong, Hong Kong, and Macau remains low, lagging far behind London and New York. The potential capacity for passenger transport is still relatively large ${ }^{1}$. Guangzhou has entered a direct competitive situation with the six major national airport economic zones and has also been affected by the above 11 aviation hub cities. Fortunately, there are major differences in each place and Shenzhen and Guangzhou have the advantage for a strategic aviation alliance. On the other hand, in order to solve the causes of land scarcity in the urbanization process, the airport is used as the center to expand cities and create an 'airport city' where airports and urban areas are deeply integrated. The theoretical basis of airport city is the Green Economy and Smart Cities ${ }^{[2]}$. The roots can be traced back to Plato (BC380) and Howard (1902) which was described the 'Garden City'. The smart city's vision, voters, and advocacy delivery mechanisms are different. Of course, the logistics infrastructure or technology network is not enough to create a 'smart city'; other indicators including space fitting and development governance, ecological resilience and the rule of law are all necessary factors. Health and education are also the focus of smart cities. Looking for anthropological solutions, it is found that humanistic care helps to understand the social structure and achieve a balance between creativity and consistency. However, recognition, dignity, and value in cultural contacts are the foundation of mental health and a happy life. The modern smart airport city emphasizes the network, skills, tolerance, creativity, family, fun community and the ecosystem it forms ${ }^{2}$. The main dispute of aviation economy in support of hub cities between practitioners lies in solving current problems or planning long-term aviation-driven smart cities. Considering the current status of China's general airport economic zone, this paper aims to solve the empirical model, major problems and countermeasures of the aviation economy supporting the hub city.

\section{Typical Models of Aviation Economy Supporting Hub City in the World}

\section{Anglo-American 'Airport City Cluster' Model}

The Bay Area of New York has three airports: Kennedy International Airport, Newark Liberty International Airport, and LaGuardia Airport. With a passenger throughput of 130 million yuan, New York has consistently ranked first place among the world's top 10 passenger aviation hub cities, and world's largest passenger throughput aviation city. For ease of management, New York State and New Jersey jointly established a cross-regional administrations ${ }^{[4]}{ }_{--N e w}$ York and New Jersey Port Authority, which greatly enhanced the overall coordination of airports, ports and other infrastructure. The Port Authority of New York and New Jersey flexibly regulates air transport capacity through various measures such as policies, prices, and charges. As a result, some large airports with oversaturated capacity and low service quality can divert some passengers to other small and medium-sized airports. Due to the unified supervision and coordination, all airports can participate in regional competition with independent property rights. In addition, moderate competition should be maintained within multi-hub airport systems. Before 2006, the London Bay Area multi-airport system took advantage of the privatization of the British Airports Authority (BAA), with property rights as a link, it finally achieved differentiated development through market segmentation and division collaboration. However, due to the monopolistic operations of BAA, which greatly restricted competition, resulting in inefficient airport operations and severely degraded aviation services. And the legitimate rights and interests of passengers and airlines were damaged. According to a study by Joseph Stiglitz, the monopoly of the BAA resulted in the loss of 
a time value up to 680 million pounds of 68 million passengers at Heathrow Airport per year4. In order to solve this problem, the British Antimonopoly Investigation Committee forced the BAA to sell the shares of two airports, thereby effectively avoiding market monopolistic behavior. The British Airports Authority only retained the holding of the Heathrow Airport. Thus, it renamed Heathrow Airport Holdings. At the same time, in order to reduce service prices and improve service efficiency, the British government set up an 'Independent Aviation Management Committee' to vigorously supervise airports. Therefore, the British-American 'airport city cluster' is typically characterized by aviation supervisors' 'regional alliances' and 'moderate market competition'. This model succeeded in New York and London. The Beijing-Tianjin-Hebei Area centered on Beijing draws on this model. The effect has begun to appear. Beijing has achieved a passenger throughput of 100 million.

\section{European 'Integrated Small and Medium-sized Business Airport' Model}

Frankfurt Airport and Schiphol Airport are also successful cases of sustained development of aviation economy. Expect for their unique geographical advantages, the key to their success lies in the emphasis on human services, public welfare management models, and the concept of harmonious development of airports and cities. As one of European three major aviation passenger hub airports, Schiphol Airport (1916, The Netherlands) receives more than 230,000 passengers per day on average, which exceeds the highest historical day reception $(210,000)$ of Guangzhou Baiyun Airport. In its limited space, it provided five main runways to take off and land large-scale aircrafts, three integrated travel halls with facilities for accessibility to and commercial services in and around. Schiphol's success attributes to the shipping-business-travelling accessibility service, where passengers did not need a passport, and the customs security provided by sniffing dogs and electronic surveillance supported by Dutch Anti-Terrorism and Security Association. At present, the security inspection tradition is resumed, and the measures taken by gendarmes to check carrying passengers into airport vehicles are no longer used. Since 1990s, as Schiphol has become the aviation hub portals of the Netherlands and Europe. Casinos, tulip seed shops and children's playgrounds at the airport have become the main leisure facilities for sticking passengers. RAI International Conference and Exhibition Center is a 15-minute drive from the airport attracting many business passengers. Schiphol has always been a well-known aviation city in the world. Similarly, Frankfurt Airport, which is one of the three major airports in Europe, occupies only 19 square kilometers. In the neighboring airport economic zone, there are 9 international five-star hotels; Frankfurt has always attached importance to airlines and sent commissioners to follow up with airlines, listen to their needs, provide in-depth analysis of aviation business, pay attention to freshmen, and provide free advertising services for new routes to help open up the market. Additionally, Frankfurt Fair has an excellent geographical advantage, close to the airport, only 15 minutes' drive from the departure hall. Frankfurt Airport has established the world's leading 'transit time' restriction: the longest transit time is 45 minutes and the best transit time is 35 minutes. According to this standard, the airport has designed a very simple transfer process, which greatly shortens passengers' transit time. Moreover, a special website has been designed to guide passengers to travel, leisure and entertainment activities near the airport. In short, the main feature of the European 'integrated small and medium-sized business airport' is to provide 'transportation-leisure-tourism access services' and efficient use of 'passenger transit time'. And it pays attention to the harmonious development in 'air-port-city'.

\section{The 'One City and Two Regional Airport Transportation' Model in Shanghai, China}

Since Shanghai Hongqiao entered the S-curve of the aviation business ${ }^{[5]}$, even if Shanghai increases its investment during the bottleneck period, it cannot increase its passenger volume and aviation noise cannot be effectively controlled. At that time, busy travelers especially disliked airports in remote locations. A large number of passengers rushed to the city center, passenger traffic at the airport had a huge impact on the city. Therefore, summing up the experience of 
aviation operations in air-rail transport and baggage checking, Shanghai opened Pudong Airport in the area adjacent to the port. Gradually, the two airports in Shanghai have shown a trend of differentiation. Hongqiao's main tasks are domestic flight takeoffs and landings, point-to-point charter flights, Shanghai city center merchant services, abdominal warehouse cargoes, international flights standby, and other airline integration merchant services. Pudong serves international flights, international merchants, passenger transport, and cargo plane. The specific strategies adopted by Hongqiao Airport for the inflection point of the passenger transportation business are: Firstly, the expansion of the aeronautical-commercial integration terminal building; secondly, the optimization of the airport landside transportation system ${ }^{[6]}$. Now buses use parking yards, two-lane closed taxis road systems, taxi dispatches and vehicle grouping stop services to improve passenger satisfaction and reduce road walking insecurity. The experiences of Shanghai Airport in noise reduction, runway reconstruction, integrated commercial facilities planning for the new terminal building, landside transportation system reconstruction, airline integration services, and 'one-city two-airports' development are worthy of reference from Guangzhou and other national airport economic zones [6,7]. The successful transition of Shanghai Hongqiao and the high-end positioning of Pudong Airport directly draw on the experience of integrated airport design of Schiphol Airport City, Frankfurt Airport City, Atlanta Airport and Los Angeles Airport, and the fine use of land in the temporary area. The centralized business service facilities also learned lessons from the over commercialization of the terminals of the U.S.-owned non-commercial airport and the impact of the passages on passenger travel. In particular, neighboring cities such as Suzhou and Hangzhou have also provided barrier-free rail transport services. The main features of Shanghai's 'one city two airports' model are focusing on 'business services' and differentiated development of 'air-rail passenger transport'. Liu Wujun's S-curve on airline business and the development of inflection point theory deserve warning.

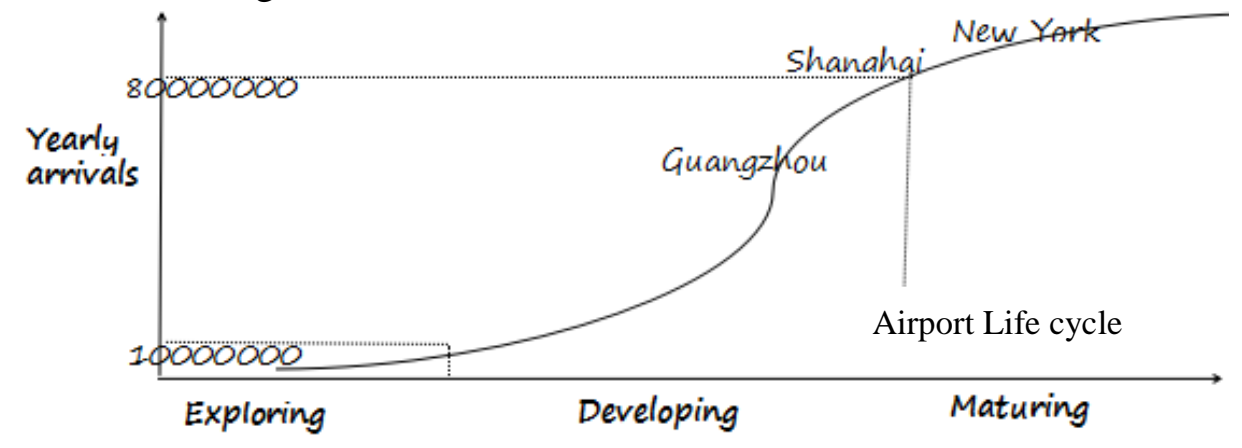

Figure 1. Aero Service S-curve

\section{'Aviation Free Trade Zone' Model in Zhengzhou, China}

In 2014, the success of the aviation economic pilot zone of Xinzheng International Airport made Xinzheng International Airport one of the busiest airports in China ${ }^{[8]}$. Different from the passenger hub cities, Zhengzhou currently has 20 million passengers and the economic benefits exceed the air ports of nearly 100 million passengers. Its success lies in increasing the economic development of logistics flow around the airport, relying on industrial added value, adjusting and supporting cross-border e-commerce and smart terminal equipment. Around 2010, Zhenzhou saw the potential of mobile phones as smart terminals and opened up the situation with Apple's maintenance. It has attracted more than 30 mobile phone accessories such as Apple, Foxconn, Guowei, Lezhou, Qiku, Nianfu, and Shangmaotong, appealed to a total number of 26 supporting enterprises including ZTE, Tianyu, Zhiyuan, Huashiji, and Winning (16 complete machine companies). The Xinzheng Comprehensive Bonded Zone has set the record of the highest growth rate (and even the record of slowdown) of the state-level airport economic development zone, especially the logistics-type flow economy. In 2016, Zhengzhou successfully upgraded to the China (Henan) Free Trade Pilot Zone on the basis of the Xinzheng Comprehensive Free Trade Zone and the Zhengzhou Airport Pilot 
Zone. It is committed to replicating and drawing upon the customs clearance policies of foreign aviation cities, aviation hub cities, and China Shanghai Free Trade Zone, convenient approval process, loose and open investment policies, such as'early access to national treatment ','negative list', 40 principles of Shanghai Financial Open Innovation Pilot, convenient entry of transit passengers and opening up of cultural industries. It would attract more logistics and people gathering in airports and once again accelerate the development of the aviation economy, optimize the industrial layout, enhance the company's global competitiveness. Then stimulate the development of the periphery, exerting the polarization effect ${ }^{[8]}$. The success of Zhengzhou lies in the success of freight hub cities and logistics-based traffic economy. First of all, it seized the key period for the mobile phone to become a nationwide consumer, with industry above the scale and industry 4.0 manufacturing as the main leading industry through the aviation logistics and cross-border electricity supplier to live the aviation economic experimental zone. Its forward-thinking ideas and industrial cultivation have inspired China's airport-oriented economic zone centered on logistics. Cao Yunchun (2011) believes that relying on aviation, the 'Zhengzhou Model' that drives the development of the airport economic zone has opened up a new model of inland regional economic connectivity and international economic development. Such a carrier accelerates the realization of 'Central China Dream' ${ }^{[8]}$. In short, the key to the success of the 'Zhengzhou Aviation Free Trade Zone' is to improve the 'flow economics' effect of freight hub cities and to use 'aviation - logistics - high-end manufacturing as the main body, nurturing and distributing related industries in the free trade zone'.

\section{'Air and Land Passenger Transport' Model in Hong Kong and other Asia Area}

The Hong Kong International Airport has not only effectively increased its freight flow but has also been very early devoting its efforts to increase passenger flow at the airport. Hong Kong's passenger transport services have always been the world leader. Hong Kong especially pays more attention to flexible buses and gradually forms a unique 'air and land integrated passenger transport' model, passengers taking free buses can directly reach the terminal downstairs. The Hong Kong Island bus and consignment services related to Hong Kong and the Pearl River Delta are worthy of reference for the passenger transport aviation hub city. By 2017, Hong Kong has also opened A3 series air buses with Chengdu, Chongqing and Yiwu to transfer Chinese passengers departing from Hong Kong to foreign destinations.

Incheon Airport in South Korea also conducts land and sea integrated passenger transport in the 'Lingnan Tourism Circle'. Passengers travelling to Incheon Airport can travel around Incheon for up to 144 hours via local airport travel coaches. This increased the number of passengers traveling from Incheon Airport to neighboring cities, and also increased the passenger throughput of neighboring cities to Incheon. Apparently, its excessive reliance on the location of tourists from China has led to a significant drop in passenger throughput when the two countries' diplomatic relations turned cold.

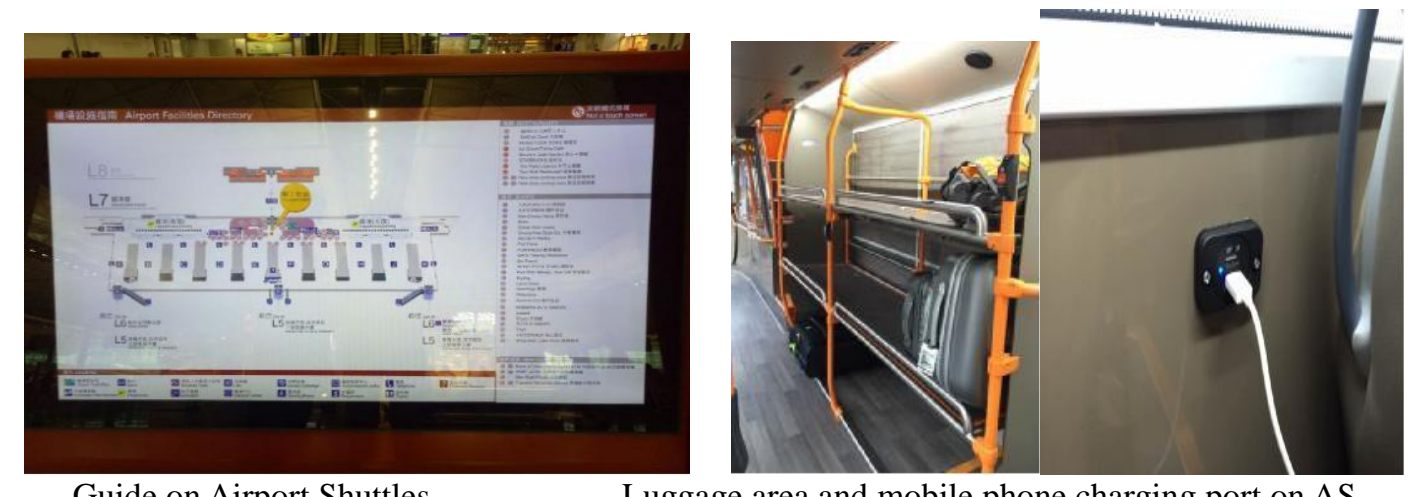

Guide on Airport Shuttles

Luggage area and mobile phone charging port on AS

Figure 2. Passenger facilitation services for Hong Kong public air transport 


\section{Aviation Economy Competition under the Guangdong-Hong Kong-Macao Great Bay Area}

The nodes of the Guangdong-Hong Kong-Macao Grand Bay area that are cooperating to gather trade and business lie in the allocation of market resources, free flow of talents, funds, goods, services, and information. In aviation economy, it is necessary to achieve industrial economic integration of logistics transportation, logistics + business MICE tourism, and even logistics + business MICE tourism + related high-end manufacturing.

\section{Major Analysis Indicators of Aviation Economy in Guangdong-Hong Kong-Macao Great Bay Area}

As it can be seen from the table below, Hong Kong International Airport has the largest volume of passengers in the Great Bay Area. The airport has the best passenger turnover capacity, highest volume of cargo and mail and most active trade activity. Two years ago, Hong Kong visitors were far behind visitors in Guangzhou. However, Hong Kong's passenger growth was staggering. Meanwhile, as the top five international airports in this region, it also exceeded the throughput of other international travelers in Meizhou, Shantou and Huizhou. These airports are responsible for Guangdong, Hong Kong and Macau's major foreign communication activities and have potential powers for international discourse. They are the major airports in Guangdong, Hong Kong and Macau.

Table 2. Transportation scale of the five airports in the Great Bay Area in 2017

\begin{tabular}{|c|c|c|c|c|c|}
\hline Airport & $\begin{array}{l}\text { Distance from the city center (main } \\
\text { facilities, unique services) }\end{array}$ & $\begin{array}{c}\text { Yearly } \\
\text { Passenger } \\
(1,000 \\
\text { arrival })\end{array}$ & $\begin{array}{c}\text { Yearly } \\
\text { Freight } \\
\left(\begin{array}{l}1000 \\
\text { tons })\end{array}\right.\end{array}$ & $\begin{array}{l}\text { GDP } \\
\text { per } \\
\text { capita } \\
(1000)\end{array}$ & $\begin{array}{l}\text { Permanent } \\
\text { residence } \\
(\mathbf{1 0 0 0})\end{array}$ \\
\hline $\begin{array}{l}\text { Guangzho } \\
\text { u Airport }\end{array}$ & $\begin{array}{l}28 \mathrm{~km} \text { (crossborder e-commerce, } \\
\text { online check-in) }\end{array}$ & 65800 & 1780 & 153.1 & 13500 \\
\hline $\begin{array}{l}\text { Shen zhen } \\
\text { Airport }\end{array}$ & $\begin{array}{l}32 \mathrm{~km} \text { (close to large exhibition hall, } \\
\text { air cargo, German Beer Festival) }\end{array}$ & 45610 & 1150 & 181.4 & 11900 \\
\hline $\begin{array}{l}\text { Zhuhai } \\
\text { Airport }\end{array}$ & $\begin{array}{c}37 \mathrm{~km} \text { (near the exhibition, holiday } \\
\text { center, land and sea integrated } \\
\text { passenger transport) }\end{array}$ & 9210 & 37 & 153 & 1670 \\
\hline $\begin{array}{l}\text { Hong } \\
\text { Kong } \\
\text { Airport }\end{array}$ & $\begin{array}{l}34 \mathrm{~km} \text { (near the exhibition hall, public } \\
\text { transport, with small aircraft docking, } \\
\text { online ordering and airport pick-up } \\
\text { service) }\end{array}$ & 72860 & 5000 & 304 & 7180 \\
\hline $\begin{array}{l}\text { Macau } \\
\text { Airport }\end{array}$ & $\begin{array}{c}\text { Downtown (Virtual Terminal Services, } \\
\text { Green Airport) }\end{array}$ & 7100 & 160 & 445.3 & 650 \\
\hline $\begin{array}{l}\text { General } \\
\text { Comment } \\
\quad \text { s }\end{array}$ & $\begin{array}{l}\text { Shenzhen is jointly held by Airport } \\
\text { Group and Lufthansa Cargo Co., Ltd.; } \\
\text { Macau aims to build an integrated } \\
\text { medium-sized airport; Hong Kong is } \\
\text { committed to the sustainable } \\
\text { development of aviation business and } \\
\text { build aviation city, the passenger } \\
\text { growth is amazing }\end{array}$ & 20058 & 8127 & 1243.8 & 14900 \\
\hline $\begin{array}{l}\text { Average } \\
\text { situation }\end{array}$ & $\begin{array}{l}26.2 \mathrm{~km} \text { (over the average distance, } \\
\text { basically provide large passenger } \\
\text { center or passenger transport services) }\end{array}$ & 40116 & 1625.4 & 870 & 6980 \\
\hline
\end{tabular}

\section{Analysis on the Advantages of the Five Airports, China}

Hong Kong Airport has a leading position in international passenger and freight transport. Although the largest number of passengers was overtaken by Hong Kong, Guangzhou Airport is one of the three major hub airports in China. It is a composite aviation hub of China's gateway, 
mainly connecting passenger and freight bridges in the mainland, especially in Southern China and international markets. It is vigorously exploring international destinations and routes. And It is expected more navigable cities and also connect with multi-world routes; Shenzhen Airport mainly undertakes domestic transportation business; Zhuhai Airport is an international air exhibition center; Macau Airport is a multi-functional small and medium-sized international airport with advantages of low-cost transportation and major services to the Asian market. The resident population has boosted the effectiveness of passengers. These five airports have different strategy for whether to closely build large-scale exhibition halls, resort centers, or provide charter service for small passenger aircraft, passengers who prefer Internet shopping. Judging from the index of passenger traffic, GDP per capita, and freight volume driven by the resident population, Guangzhou, as a central city in Guangdong-Hong Kong-Macau Bay Area, has yet to maintain the advantages of domestic tourists and commit to expand international aviation.

\section{Problems and Countermeasures in the Process of Guangzhou Managing the Destination as Aeronautical Passenger Hub City}

Passengers transiting through the city airport portal can only convert to tourists after staying for more than 4 hours or overnight. So that it can integrate aviation logistics to produce tourism economic and social benefits for the local airport. Liu Wujun and Gu Chengdong (2014) believe that with the opening of the Guangdong-Hong Kong-Macao Bridge, the traffic structure in Pearl River Delta will have significant changes. And it will turn into a triangle (Figure 3) [7]. In fact, the Guangzhou Airport Economic Zone is a major masterpiece of Guangzhou's construction of an aviation hub city. The inter-city trajectory in between cities will soon accelerate the rapid transformation of the original pattern of Pearl River Delta urban agglomeration. On the one hand, the most beneficiary is Zhuhai, followed by Macau. And the benefits of Zhuhai and Macau will directly undermine the entire Guangdong, Hong Kong, and Macau's carrying capacity, such as Guangzhou, if they do not become bigger and stronger together. On the other hand, the opening of the Guangdong-Hong Kong-Macao Bridge has also provided preliminary conditions for aviation strategic alliances in Guangdong, Hong Kong, and Macau Bay Area with the abrupt changes. Regional aviation cooperation, international route misplacement, passenger transport, and advance boarding are easier to operate because of shorter distance, frequent exchanges and punctual intercity transportation.

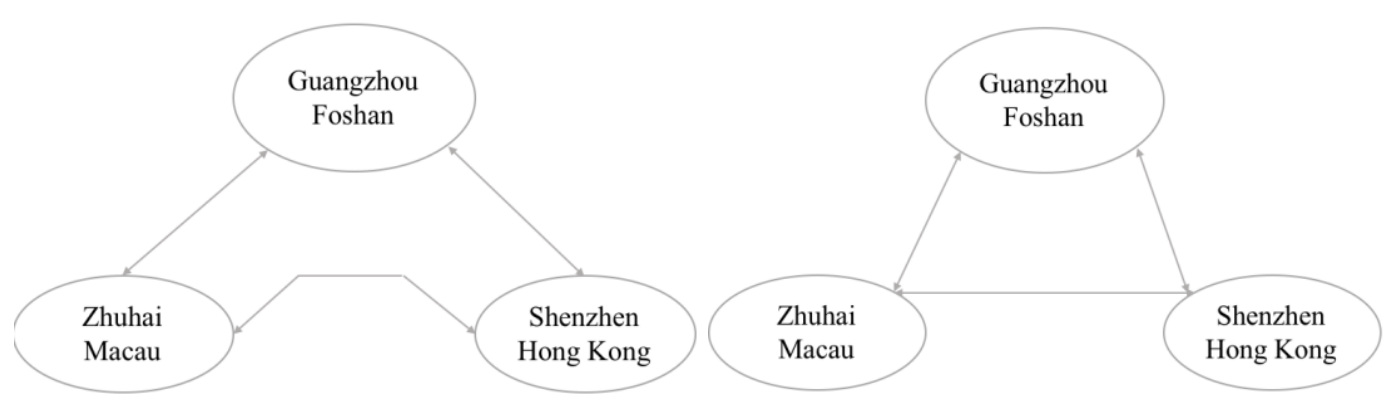

Figure 3. Changes of the PRD traffic structure by the Guangdong-Hong Kong-Macao Bridge

In the new era, Guangzhou should focus on the passenger transport hub and build a high-level airport development zone to develop aviation hub city. The main manifestations are:

First, the planning and implementation in core area and pillar industries of airport economic zone are too conservative to meet current passenger demand. It is necessary to introduce advanced industrial manufacturing companies and hi-tech industries such as smart manufacturing and shared cars. It is also helpful to consider developing exhibition industry where Guangzhou has advantages, as well as financial, shopping, entertainment, catering, medical, and other industries to reactivate 
the rapid growth of aviation business. The issue of upgrading of land-side traffic is serious. In addition, Guangzhou Baiyun Airport is about to enter the inflection period (70-80 million passengers per year) during which the aviation business is slowing down. Busy passenger flow not only impacts the airport's business and travel services, but also affects the city that it is attached to. When it comes to the bottleneck of aviation services on the cultivation of airport industries and the transformation of endogenous services, it is worth studying the experience of Zhengzhou, Shanghai and the United States in the airport economic zone.

Second, we must improve the service industry distribution and service concept within the airport. Focusing on changing the inherent operating philosophy of state-owned airlines, paying attention to passenger transport services, conducting off-site boarding and baggage check services, conducting market surveys on the needs of mid-range and family travelers. Airport passengers' consumption behavior data in Guangzhou must be published to guide more air economic research. Comparing domestic and international high-end airports where passengers transport is always busy. Guangzhou, for example, should change the inherent thinking of passenger transport services, strengthen the integration of passenger transport and airport transportation in the Pearl River Delta, and make use of the linkage capabilities and punctual characteristics of Guangzhou Intercity Light Rail and the Pearl River Delta in particular, arrange boarding and baggage check in advance. Additionally, it has to support the groundwork employees in surrounding administrative regions to the improve passenger transfer efficiency, like barrier-free accessibility to the airport-public welfare bus in Hong Kong. Intermodal passenger transport has a lot of experience in the Yangtze River Delta cities. Changi Airport and European business airports have more programmatic services for improving transit efficiency which we can learn from.

Third, study the existing management system and solve the difficulty to attract investment. There are 19 square kilometers land with most business potential near Baiyun Airport. It is jointly managed by Aviation Commission and the Airport Group which may cause problems such as entangled management and excessive coordination costs. Adjusting the airport management system must comply with market rules or meet the needs for resource integration. It is currently a matter of strategic choice to go for the provincial-level unified management of the airport economic zone or in accordance with group company joint venture management like Shenzhen. Other hub cities such as Zhuhai also have problems in investment promotion, lack of innovation in management system. Cross-regional aviation associations have obtained a lot of achievements referring to the Anglo-American model and the Beijing-Tianjin-Hebei strategic cooperation.

Fourth, strengthen the role of the airport as a destination and promote the airport as a window of the airport economic zone. Hire overseas returnees to manage media where Taiwan, Qingdao and Shanghai have much experience. The story of Guangzhou Airport was not appealing yet, Lingnan cultural propaganda was not well-spread. It was necessary to promote international new routes vigorously to Chinese outbound travelers. The introduction of overseas returnees to join the "high-paying civil servants" is not only a professional and technical position, but also deserves high-paying civil servants for special projects like managing the government's social media and promoting the international image of destinations. The effect will be higher than that some individual departments in Guangdong Province outsourced to companies with ten million funds.

Based on the local environment, the issues and countermeasures for strengthening the construction of passenger transport hub cities are proposed. They are also adapted to the airport economic zone and have long-term reference significance for the aviation passenger hub cities. Generally, the aviation economy supports the development of passenger transport hub cities. It is suggested when airport cities enter the inflection point of aviation services, it can promote three major aviation economies transformation ${ }^{[6]}$ : From 'Airline Expansion' to 'Endogenous Aviation Business' and 'Intermodal Airlines'; from 'outward-looking Aviation Business' to 'Inward-looking Service' and 'Regional Passenger Transport'; from 'Airport Facilities Upgrades' and 'Technical Upgrades' to 'Business Model Innovations' and 'institutional innovations' to reactivate the aviation business rapid growth again. As for Guangzhou, when constructing the public transport system in 
the airport economic zone, it is necessary to firstly consider building a second airport in the near-port area instead of aviation-port integration which can change the weak position of the freight transport. For passenger transport business, it is suggested to expand its advantages of low-cost operation for domestic routes and short-haul overseas routes, strengthen road-airway transport, make use of flexible transport coaches, encourage long-distance overseas routes with Hong Kong and Macau, and moderately independently developed special international routes; We must take the advantages of the airport's portals when promoting, employ internationalized civil service teams to promote destinations and improve international discourse rights. Airport system research has reached a critical time if we consider strengthening airport's urban mission or reduce the dual burden of the government's market operations and supervision.

\section{Acknowledgement}

This paper was sponsored by the Guangdong Provincial Department of Transportation Science and Technology Project (2015-02-064), and we especially thank Yue Chaoyang, Wei Fulian, Zhang Zhuoxiang of China Zhigong Party for their communication and coordination in the accomplishment of this topic. Prof. Yang Li, Wu Xinling from South China Business College of Guangdong University of Foreign Studies, and Dr. Tom Bu from Hong Kong Polytechnic University also put forward constructive suggestions on the writing of this paper.

\section{References}

[1] J D Kasarda. Logistics \& the Rise of the Aerotropolis. Real Estate Issues, 2000(4):43-48.

[2] J D Kasarda. Global Airport Cities, Twickenham: Insight Media, 2010. P41

[3] L. van den Berg et al. Airports as centres of economic growth. Transportation Review, 1996, 16(1): 55-65

[4] Regional ports concentrate on growth and connectivity. Logistics Management, 2016(7): 54-59

[5] Wujun Liu. Hongqiao international airport planning, Shanghai: Scientific and Technical Publishers, 2016

[6] Wujun Liu. Aviation hub planning. Shanghai: Scientific and Technical Publishers, 2013

[7] Wujun Liu, Gu Zedong. Research on the public transport development strategy of bridgehead ---Zhuhai, Shanghai: Tongji University Press, 2014

[8] Yunchun Cao. The growth space of aviation in the era of economic speed, Beijing: Economic Science Press, 2009

[9] Yunchun Cao. Study on the construction of high-tech industrial system in Zhengzhou Airport. Traffic and Transportation, 2011 (7): 140-144 